University of Nebraska - Lincoln

DigitalCommons@University of Nebraska - Lincoln

Faculty Publications, UNL Libraries

Libraries at University of Nebraska-Lincoln

2012

Continuing Education for Distance Librarians

Mary Cassner

University of Nebraska - Lincoln, mcassner1@unl.edu

Kate E. Adams

University of Nebraska - Lincoln, kadams1@unl.edu

Follow this and additional works at: https://digitalcommons.unl.edu/libraryscience

Part of the Library and Information Science Commons

Cassner, Mary and Adams, Kate E., "Continuing Education for Distance Librarians" (2012). Faculty Publications, UNL Libraries. 271.

https://digitalcommons.unl.edu/libraryscience/271

This Article is brought to you for free and open access by the Libraries at University of Nebraska-Lincoln at DigitalCommons@University of Nebraska - Lincoln. It has been accepted for inclusion in Faculty Publications, UNL Libraries by an authorized administrator of DigitalCommons@University of Nebraska - Lincoln. 
Published in the Journal of Library \& Information Services in Distance Learning (2012) 6(2): 117128. DOI: $10.1080 / 1533290 X .2012 .694338$. The published version of the article is available at: http://dx.doi.org/10.1080/1533290X.2012.694338. Copyright 2012, Taylor \& Francis. Used by permission.

\title{
Continuing Education for Distance Librarians
}

\author{
Mary Cassner ${ }^{a} \&$ Kate E. Adams ${ }^{b}$
}

${ }^{a}$ CY Thompson Library, University of Nebraska-Lincoln, Lincoln, Nebraska, U.S.A.

bLove Library, University of Nebraska-Lincoln, Lincoln, Nebraska, U.S.A.

Distance librarians as engaged professionals work in a complex environment of changes in technologies, user expectations, and institutional goals. They strive to keep current with skills and competencies to support distance learners. This article provides a selection of continuing education opportunities for distance librarians, and is relevant for all practicing librarians. Suggestions include physical and virtual conferences, professional journals for reflective reading, short-term webinars about current topics and innovative approaches, blogs for sharing ideas, and discussion and interest groups for networking with colleagues about best practices, leadership, and serving academic populations.

KEYWORDS: Continuing education, distance education, academic librarians, career development, professional development

\section{INTRODUCTION}

Academic librarians have been sharing ideas for supporting distance learners, as evidenced by Guidelines for Library Services to Extension Students ${ }^{1}$ and the 1981 Guidelines for Extended Campus Library Services, ${ }^{2}$ both from the Association of College \& Research Libraries division of American Library Association. Subsequent revisions have followed, with the current Standards for Distance Learning Library Services approved by the ACRL Board in 2008. ${ }^{3}$ Since 1982, Central Michigan University has organized and hosted international conferences for distance librarians, administrators, and educators to discuss trends, theories, and technologies related to providing library services to distance students. The Off-Campus Library Services Conference has been biennial since 1988, and with the 15th conference in April 2012, changed the name to Distance Library Services Conference. Today distance librarians as engaged professionals work in a complex

Address correspondence to Mary Cassner, University of Nebraska-Lincoln, Lincoln, Nebraska, U.S.A.; mcassner1@unl.edu

Version of record first published: June 11, 2012. 
environment of change with multiple technologies, institutional changes in higher education, and shifting user expectations. Librarians strive to keep current with skills and competencies to expand their knowledge base. Enhanced skills and competencies support the distance librarian's immediate work with distance learners in undergraduate and graduate programs, and expand the foundation for anticipated future responsibilities and professional advancement.

One consideration in participating in continuing education opportunities can be funding for conferences and webinars. Libraries may allocate monies on an annual basis for this purpose. Other sources include grants sponsored by the librarian's college or university, state library associations or government library agencies, and scholarships offered by the sponsors of a particular conference or webinar.

This article identifies continuous learning opportunities that were chosen to meet distance librarians' time and workload commitments as well as personal learning preferences. These opportunities include conferences, short-term webinars about current topics and innovative approaches, blogs, and discussion and interest groups for networking with colleagues about best practices, leadership, and serving academic populations. Professional journals for reflective reading and self-directed learning are essential parts of continuing education and professional development. The multitude of choices help engaged practitioners, whether newly hired, mid-career, or senior, address continuing education needs for professional and personal learning in a rapidly changing environment. The selections are intended for distance librarians, but are relevant for all practicing librarians.

The ACRL Statement on Professional Development outlines the expectations for librarians to engage in continuous learning. ${ }^{4} \mathrm{~A}$ few articles provide an overview related to continuing education specific to distance librarians. As a librarian new to distance education, Jones surveyed and interviewed experienced distance librarians. Comments included that it was important to network with other librarians by conference attendance, serving on committees, and through participation in mail lists for distance librarians. Not surprisingly, it was noted that librarians should also try to keep informed of new technologies. ${ }^{5}$ Fritts and Casey studied training and development needs of distance librarians. Survey responses indicated a strong desire for library and information degree programs to increase course content related to distance learning librarianship and for the American Library Association's Distance Learning Section to increase training opportunities. ${ }^{6}$ Cassner and Adams surveyed distance librarians on their professional development needs. Distance learning conferences, listservs specifically for distance librarians, and professional journal articles were found to be most useful by distance librarians with blogs increasing in importance. ${ }^{7}$ 


\section{CONFERENCES}

This section highlights conferences that focus on distance learning and technologies. Conferences provide opportunities to learn from experts in the field and to network with colleagues. They include an array of programs, presentations, workshops, and committee service.

- Distance Library Services Conference, http://ocls.cmich.edu/conf 2012: Librarians who work with distance students, educators, and administrators share their research and experience. This biennial conference, sponsored by Central Michigan University, offers presentations, posters, panels, discussion groups, and workshops. Conference proceedings are published. Papers are reprinted in Journal of Library $\mathcal{E}$ Information Services in Distance Learning. Topic tracks for past conferences include research, teaching and learning methods, electronic information and delivery, collaboration, and administration. Conferences are held in the spring at various sites.

- Annual Conference on Distance Teaching \& Learning, http:/ / uwex. edu/disted/conference: This international conference highlights current research and best practices with teaching, technology, and program management. Program tracks include higher education, K-12, business and industry, government, military, and global learning. The conference is held in Madison, Wisconsin, each August.

- Distance Learning Administration Conference, http://www.westga. edu/ distance/dla: The conference, sponsored by the Online Journal of Distance Learning Administration and the University of West Georgia, focuses on administration, management, planning, and evaluation of distancelearning.ItisheldannuallyinMayorJuneatvarioussitesinGeorgia.

- Brick \& Click, http:/ / www.brickandclick.org: This one-day conference of concurrent and lightning-round sessions emphasizes new technologies, practical solutions, and current topics presented by practitioners from around the country. It is held each Fall at Northwest Missouri State University in Maryville, Missouri.

- EDUCAUSE, http://www.educause.edu: This nonprofit association aims to advance higher education through strategic use of information technology. Annual conferences are held in fall at various sites with virtual attendance a possibility. The two-day regional conferences are held in the Mid-Atlantic, Midwest, Southeast, and West/Southwest. Options include half-day, single day, and full conference registration.

- Sloan Consortium (Sloan-C), http://sloanconsortium.org: This is a consortium of organizations and institutions dedicated to improving the quality, scale, and breadth of online programs. The Annual Sloan Consortium International Conference on Online Learning is held in fall, the Annual Sloan International Symposium for Emerging Tech- 
nologies for Online Learning in summer, and the Annual Sloan Consortium Blended Learning Conference \& Workshop in spring. These conferences meet at various sites. Sloan-C also offers an Online Education Research Symposium Series and free webinars. Membership may be institutional or individual.

- Subject or discipline related conferences-Distance librarians who have subject liaison responsibilities may choose to attend a subjectspecific conference sponsored by the academic discipline or professional organization. Subject conferences are venues to learn about new trends in research areas, current methodologies, and technologies in use. The professional literature includes articles listing sources for identifying subject conferences. Relevant Web sites include: AllConferences.com http:/ / www.allconferences.com, American Council of Learned Societies http://www.acls.org (with a focus on humanities and social sciences), and Conference Alerts http://www. conferencealerts.com.

\section{ASSOCIATIONS AND ORGANIZATIONS}

This section provides links to national, regional, and state library and educational associations and organizations with an interest in distance learning. Membership in professional associations and organizations can provide many benefits including the opportunity to network with other librarians. Associations offer conferences, webinars, blogs, and the opportunity to serve on committees. Frequently they produce journals and may offer member-only access to information on its Website.

- American Library Association (ALA), http://www.ala.org: The organization comprises 11 divisions and 19 round tables arranged by specific interests. Over 200 discussion groups provide a venue for members to converse on a variety of topics. ALA Annual Conference has programs, discussion groups, and committee meetings.

ALA Online Learning, http://www.ala.org/onlinelearning: provides many opportunities for continuing education through courses, webinars, webcasts, and e-forums, with offerings listed on Web pages of ALA divisions and offices. Online webinars offered in the past included Constructing the Future Library, Finding Savings in the Collection Budget, The Consortial-Campus View, Reference Collections: Strategies for Managing Change, and How to Present a Webinar.

- ALA. Association of College \& Research Libraries (ACRL), http:// www.ala.org/acrl: This division has more than 12,000 members as of 2011, with 17 sections as well as discussion and interest groups. ACRL and its sections sponsor programs of interest to its members at the ALA Midwinter and Annual Conferences. Preconference workshops are frequently offered. An ACRL conference is held every two years at 
different cities in the United States. ACRL also conducts topic-specific immersion programs and scholarly communication institutes.

E-Learning opportunities include ACRL multi-week online courses and interactive webcasts. ACRL On Point Chat consists of informal monthly chat sessions related to academic librarianship, with archives of chat logs available on the ACRL Website. The ACRL Frequent Learner Program offers free online courses and webcasts to groups or individuals with multiple registrations. E-Learning scholarships are available to ACRL members. Subscribing to ACRL eLearning RSS feeds can help librarians stay informed of new e-Learning opportunities.

- ALA. Association of College and Research Libraries. Distance Learning Section. (DLS), http://caspian.switchinc.org/ distlearn: The DLS Section connects librarians from around the world face-to-face at ALA annual and midwinter conferences and virtually. Most DLS committees have virtual committee appointments, and often meet via Web-conference. (See DLS committee information under Committee heading.) The Section maintains the OFFCAMP listserv (subscribe listserv@listserv.utk.edu). DLS hosts a social at annual and midwinter conferences. In 2011 there were over 1,500 members in DLS.

- ALA. Association of College and Research Libraries. Instruction Section. (IS), http://www.ala.org/acrl/aboutacrl/directoryofleadership/sections/is/ website: The section offers teaching methodologies and support to librarians who provide library instruction and teach information literacy in higher education. IS has held virtual Midwinter Conferences for the past three years, with meetings held in November and early December. Current Topics Discussion Groups address timely instruction-related topics. The section maintains the ILI-L Information Literacy and Information listserv. Section committees often have one-year intern positions, with responsibility for taking and distributing minutes. The IS Mentoring Program Committee connects experienced instruction librarians with librarians who are new to instruction. The section holds socials at both Midwinter and Annual Conferences.

Instruction librarians who have developed effective information literacy tutorials can submit them for inclusion in the Section's PRIMO (Peer-Reviewed Instructional Materials Online) database, http://www.ala.org/apps/primo/public/search.cfm. Projects accepted in PRIMO demonstrate effective teaching strategies in a networked environment.

-ALA. Library Information \& Technology Association (LITA), http:/ / www.ala.org/lita: This division offers one-time webinars and Web courses on emerging technologies within the library and information environment. Examples of webinars include Using Scrum to Streamline Web Applications Development and Roadmap to JPEG2000. The 
Web course, Creating Library Web Services: Mashups and APIs, has been offered several times.

LITA National Forums are held annually in fall at various locations. The Forum offers concurrent sessions, poster sessions, and a Sponsor Showcase which provides a venue for displaying and discussing leading edge technologies and services. LITA regularly sponsors preconference workshops. Prior workshops included Open Source CMS Playroom, Getting Started with Drupal, and Digital Curation at the Command Line. LITA Regional Institutes are single-day workshops on technology-related topics, such as Writing for the Web, Establishing an Institutional Repository, User Centered Design, Wireless Networks in Libraries, and XML in Libraries. LITA interest groups, http://www.ala.org/lita/involve/igs, are a venue for learning about emerging trends and issues in library technology. LITA interest groups are open to all LITA members, and do not require attendance at annual or midwinter conferences. Distance Learning, Emerging Technologies, and Transliteracy are some of the 25 interest groups.

-ALA. Reference \& User Services Association (RUSA), http://www. ala.org/rusa: Offers webinars and online courses with registrations for individuals and groups. Online courses recently offered included Introduction to Spatial Literacy and Online Mapping, Business Reference 101, Genealogy 101, Health Information, Readers' Advisory, Reference Interview, and Beyond Compliance: Assuring Equitable Access to Library Services for All Library Users. RUSA produced its first webinar in August 2011, Introduction to Screencasting Tutorials, and plans to increase offerings in 2012.

-ALA. Library Instruction Round Table (LIRT), http://www.ala.org/ lirt: This organization promotes library instruction and information learning. The Website contains a variety of information resources such as Evaluating Library Instruction, Teaching Tips, Tutorials, and Top 20 Instruction Articles.

- ALA. Regional and State Chapters, http:/ / www.ala.org/groups/affiliates/chapters/state/stateregional: Regional and state chapters sponsor continuing education activities. Regional chapters of ALA include Mountain Plains Library Association (MPLA), New England Library Association (NELA), Pacific Northwest Library Association (PNLA), and Southeastern Library Association (SELA). Regional chapter Web sites list officers as well as conference and newsletter information. State library associations or chapters are affiliated with the American Library Association. A list of these organizations is found on the ALA Website along with links to officers, addresses, and conference information. State library associations and/or state government library 
agencies provide links to continuing education opportunities on the local, regional, and national level.

- Special Libraries Association (SLA), http://www.sla.org: The Special Libraries Association is organized by geographic chapters, topical divisions, and special interest caucuses. SLA's Continuous Learning to Improve Career Knowledge, or CLICK University, has several options for professional development. Webinars provide access to live interactive presentations on a variety of subjects. Previous webinars include Managing Digital Information, Organizational \& Professional Development, Internet Practices \& Web Performance Improvement, and Ask the Copyright Experts. The Innovation Laboratory, a CLICK University program, provides software learning tools to selected SLA chapters, divisions, caucuses, and committees. Leadership training programs are offered by some SLA chapters and divisions. The Association also operates a number of division, chapter, and general blogs.

- LOEX, http://www.emich.edu/public/loex/loex.html: This nonprofit organization serves as a clearinghouse to members for library instruction and information literacy materials. The organization sponsors an annual conference. Selected PowerPoint presentations and handouts from previous conferences are available on the LOEX Website.

- Additional Associations, http://www.directoryofschools.com/ Guide/FAQ-Glossary-and-Resources/Distance-Learning-Associations-Helping-Move-Distance-Learning-Forward.htm: Lists national, state, and global distance learning associations.

\section{COMMITTEES}

Committee service provides opportunities to work with librarians who share professional interests and/or have similar job responsibilities. Serving as a committee member or intern is a way to develop leadership skills. Committees frequently have virtual members, and work is often done via Web conferencing and wikis. Committee service is ideal for networking and meeting colleagues for potential collaborative work such as co-authoring and co-presenting. Attending committee meetings as a guest is an established way to indicate interest in being appointed to a committee.

Distance librarians might consider service in ALA's Distance Learning Section. DLS committees are filled by appointment, with volunteer applications accepted through February 15 for service beginning July 1. Terms are two years, unless otherwise noted. The committees include:

- Awards-Solicits, collects, and reviews applications for the Haworth Press Distance Learning Librarian Conference Sponsorship Award, and makes a recommendation to the DLS Executive Committee. One year term. 
- Bibliography-Publicizes research in distance learning librarianship by publishing the bibliography on Library Services for Distance Learning. The Library Services for Distance Learning: The Fifth Bibliography is available at http:/ / caspian.switchinc.org/ distlearn/ resour ces/5thBibliography/5thBibliography.html.

- Communications-Develops and issues the section newsletter and makes submissions to appropriate journals for DLS news.

- Conference Planning-Plans and organizes the section program for ALA Annual Conference.

- Discussion Group-Determines topic(s) for discussion at ALA Annual Conference and ALA Midwinter.

- Instruction-Assists section members in developing instructional materials for distance learners.

- Membership and Events - Plans the section's social and provides orientation for new members.

- Nominations-Develops a pool of candidates for section officers.

- Outreach-Represents the section officially and gathers information from other ACRL sections and units.

- Research-Promotes and facilitates research and publication in the area of distance learning library services.

- Strategic Planning-Develops recommendations regarding the section's future directions, goals, objectives, policies, and priorities, for review by the DLS Executive Committee.

\section{MENTORING}

Mentors can provide advice, assist with networking, and serve as role models for present and future positions. Mentoring programs can be found formally through ALA ACRL Instruction Section Mentoring Program, http://www.ala.org/acrl/aboutacrl/directoryofleadership/sections/is/ iswebsite/projpubs/mentoring, and New Members Round Table (for individuals with fewer than 10 years of membership in ALA), http:/ /www. ala.org/nmrt/oversightgroups/comm/mentor/mentoringcommittee. Application forms are available at these URLs. Additional ways to find mentors are through committee service and informal connections at conferences and meetings.

\section{WEBINARS AND ONLINE COURSES}

Web-based seminars provide presentations or workshops covering current topics and trends often free or at nominal cost. Webinars range from 90-minute sessions to a series of sessions offered over several weeks or months. Online seminars are also accessible via ALA Online Learning at http:/ / www.ala.org/onlinelearning, with links to ALA divisions.

Database vendors offer webinars on new or updated products. These provide training support for existing customers and can be used to advertise 
their products to potential clients. Many vendors exhibit at library conferences or make in-person visits to college and university libraries. There are also for-profit companies that specialize in offering webinars to those employed in libraries.

\section{PROFESSIONAL CONNECTIONS: BLOGS, COLUMNS, AND RSS FEEDS}

Blogs and columns offer insights and opinions from thought leaders on current issues in librarianship, technology, and education.

- American Libraries, http:/ /americanlibrariesmagazine.org: Includes monthly columns on information technology such as Internet Librarian, In Practice, and Dispatches from the Field. American Libraries E-Content, http://americanlibraries.org/e-content, focuses on information related to e-journals, e-books, databases, and other econtent.

- The Wired Campus, http://chronicle.com/blogs/wiredcampus: Covers news and opinion on technology.

- Blog U, http://www.insidehighered.com/blogs: Columns that may particularly be of interest to distance librarians include Library Babel Fish, Law Policy and IT?, Digital Tweed, and Technology and Learning.

- ACRLog, http://acrlog.org: Addresses issues in academic and research librarianship.

- ACRL Insider blog, http://acrl.ala.org/acrlinsider: Provides information on association activities including publications, conferences, and events.

- Distant Librarian blog, http://distlib.blogs.com: Focuses on library and educational technology, with many posts of interest to distance librarians.

- Online Learning Update, http:/ / people.uis.edu/rschr1/onlinelearning/blogger.html: Covers many aspects of online and blended learning including technologies, trends, and pedagogies.

Real Simple Syndication (RSS) allows users to stay current with news and blog Web sites, newspapers for stories on technology or education, and newly published journal articles. An RSS reader, such as BlogLines, Google Reader, or NetNewWire, is needed to filter and display entries from Web sites or blogs. When feeds are not available, alternative options to help monitor Web sites include Page2RSS and Watch That Page.

\section{ONLINE COURSES AND CERTIFICATES}

Another continuing education option is enrollment in classes through colleges, universities, or library school programs. 
- Online Courses-Can relate to the pedagogy of teaching such as instructional theory, information literacy instruction, e-Learning, or instructional technology. Contact sources include continuing education units at academic institutions, state library agencies, and library listservs.

- Certificate programs - San Jose State University School of Library and Information Science offers an online Post-Master's Certificate Program in Library and Informational Science, http:/ / slisweb.sjsu. edu/certificate/index.htm. The University of Wisconsin, http:// depd.wisc.edu, offers two distance education professional development certificate programs. The Distance Education Certificate Program can be completed online and comprises of four core modules: learning at a distance, instructional system design, distance education technology, and evaluation in distance education. The Professional Certificate in Online Teaching emphasizes the pedagogy and practice of online instruction.

\section{PROFESSIONAL JOURNALS}

Distance librarians can keep current by reading journal articles on topics such as education, instructional design, and assessment. Most libraries have general and specialized indexes that cover higher education, technological change, and information literacy. Journals which address distance learning include:

- American Journal of Distance Education, http://www.tandf.co.uk/ journals/titles/08923647.asp: Peer-reviewed journal published by Taylor \& Francis. Aims to disseminate scholarship and research related to American distance education.

- Distance Education, http://www.tandf.co.uk/journals/carfax/0158 7919.htm: Peer-reviewed journal published by Taylor \& Francis. Official journal of the Open and Distance Learning Association of Australia. Cover age includes scholarly and research articles related to open, distance, and flexible education.

- Distance Education Report, http://www.magnapubs.com/catalog/ distance-education-report-newsletter: Newsletter published semimonthly by Magna Publications. Especially aimed towards distance education administrators, technical staff, and faculty. Covers some topics related to library services.

- International Journal on E-Learning (IJEL), http://www.aace.org/ pubs/ijel: Peer-reviewed journal published by the Association for the Advancement of Computing in Education. Seeks to facilitate international discussion of current research, development, and practice of e-Learning related to business, government, health care, and higher education. 
- International Review of Research in Open and Distance Learning (IRRODL), http:/ / www.irrodl.org: Peer-reviewed open access journal from Athabathsca University. Covers research, theory and practice in open and distance learning.

- Journal of Distance Education, http://www.lib.unb.ca/Texts/JDE: Open access journal of the Canadian Association for Distance Education (CADE). Aims to meet the needs of Canadian distance professionals and scholars by providing a forum to disseminate international scholarship. Some text in French.

- Journal of Library \& Information Services in Distance Learning, http:/ / tandf.co.uk/journals/WLIS: Peer-reviewed journal published by Taylor \& Francis. Scope includes research, theory, essays, and literature reviews.

- Journal of Research on Technology in Education (JRTE), http://www. iste.org/learn/publications/journals/jrte.aspx: Peer-reviewed journal published by the International Society for Technology in Education. International scope with articles relating to the instructional uses of education technology.

- Online Journal of Distance Learning Administration (OJDLA), http:// www.westga.edu/ distance/ojdla: Peer-reviewed open access journal published by the University of West Georgia. Articles focus on the management of distance programs by researchers and practitioners.

- Open Learning, http://www.tandf.co.uk/journals/carfax/02680513. html: Peer-reviewed journal published by Taylor \& Francis. Publishes theoretical and evidence-based scholarly articles, shorter practical articles, and book reviews related to open, flexible, and distance learning.

- Quarterly Review of Distance Education, http://www.infoagepub. com/qrde-guidelines.html: Peer-reviewed journal published by the Association for Educational Communications and Technology. Included are research briefs, articles, reviews, and editorials related to the theories, practices, and research of distance education.

- DEHub Database of Research on Distance Education, http://www.dehub.edu.au: Funded by the Australian Department of Education, this searchable database indexes journal articles, books, conference papers, and reports related to distance and online education. While the main subject focus is Australia, DEHub also indexes some materials published in the United States.

\section{COMMUNICATION SKILLS}

Successful communication includes the ability to speak effectively.

- ToastmastersInternational,http:/ / www.toastmasters.org:Offersskillbuilding in public speaking, with meetingsinnearly every community.

- Mind Tools, http://www.mindtools.com: Contains interactive tools 
and articles that help hone skills in communication, project management, decision making, and problem solving.

\section{LOCAL CONTINUING EDUCATION OPPORTUNITIES}

The distance librarian also has continuing education options available locally. Many libraries have a staff development unit that sponsors professional development programs. Colleges and universities usually have continuing education divisions that provide residential or online lectures and workshops for campus members. University academic departments typically sponsor seminars about pedagogy and technology used in the academic discipline.

\section{CONCLUSION}

This article has identified continuous learning opportunities for distance librarians to develop new skills and competencies to reflect changing user expectations and shape the future of higher education and society. The myriad choices can assist distance librarians, whether newlyhired, mid-career, or senior, address continuing education needs for professional and personal growth.

\section{REFERENCES}

1. American Library Association. (January 1967) Guidelines for library services to extension students. ALA Bulletin 61(1): 50-53.

2. Association of College \& Research Libraries (October 1968). Standards for distance learning library services. College \& Research Libraries News 69(9): 558-569.

3. Association of College \& Research Libraries. "Standards:" 559.

4. Association of College \& Research Libraries (November 2000). ACRL Statement on Professional Development. College \& Research Libraries News 61(10): 933-936.

5. Marie F. Jones (2002). “Help! I'm the new distance librarian - where do I begin?" Journal of Library Administration 37(3/4): 397-410.

6. Jack Fritts and Anne Marie Casey (2010). Who trains distance librarians? A study of the training and development needs of distance learning librarians. Journal of Library Administration 50(5/6): 617-627.

7. Mary Cassner and Kate E. Adams (2006). Assessing the professional development needs of distance librarians in academic libraries. Journal of Library Administration 45(1/2): 71-99. 